\title{
Molecular Typing of Staph - Aureus MRSA Strains Isolated from Processed Fish in Port-Said Governorate Mohamed E. Enany ${ }^{1}$; Abdelazeem M. Algammal ${ }^{1}$; Helal, I.M. ${ }^{2}$ and Mohammed A. Soliman ${ }^{2}$ \\ ${ }^{1}$ Deptartment of Bacteriology, Mycology and Immunology, Faculty of Veterinary Medicine Suez Canal University, Ismailia, Egypt \\ ${ }^{2}$ Deptartment of Bacteriology, Animal Health Research Institute - Port Said branch.
}

\begin{abstract}
Fish products could be contaminated with bacterial pathogens such as $\boldsymbol{S}$. aureus, which could be transmitted to human causing severe illness. In order to throw the light on the presence of $\boldsymbol{S}$. aureus in fish products as well as molecular typing of MRSA strains, a total of 200 samples of processed fish products (100 fish burger and 100 fish fillet) were collected from different frozen fish stores in Port-Said Governorate, Egypt. The collected samples were subjected to bacteriological examination. The prevalence of coagulase +ve $S$. aureus was (14\%) in fish burger samples and (4\%) in fish fillet samples. On the other hand, the prevalence of Coagulase -ve $S$. aureus was (4\%) in fish burger samples and (1\%) in fish fillet samples. Antimicrobial susceptibility for methicillin was carried out for detection of MRSA strains, where the prevalence of MRSA strains was $17 \%$ from the total isolated coagulase positive $S$. aureus strains, while none of the coagulase negative $S$. aureus strains proved to be MRSA. PCR protocol was used for detection of $\boldsymbol{m e c A}$ gene in MRSA strains, where all the tested MRSA strains were positive for $\boldsymbol{m e c A}$ gene with specific amplification size at $310 \mathrm{bp}$. Briefly, S. aureus considered to be one of the major bacterial agents causing food-borne illness in human due to contamination of fish products.
\end{abstract}

\section{Introduction}

Food processing industry was aimed to supply a healthy and palatable food for the human consumers. Contamination by highly virulent bacteria could take place resulting in food intoxication (Shena and Sanjeev 2007). S. aureus is one of the most prevalent pathogenic bacteria associated with fish, which could be transmitted to human causing severe illness (Sichewo et al. 2013). Food poisoning caused by S.aureus is mainly characterized by nausea, vomiting, severe abdominal pain and diarrhea (Llewelyn and Cohen, 2002). 
Nosocomial infections have both public health importance and veterinary importance. MRSA is one of the most incriminated microorganism in nosocomial infections. MRSA strains are characterized by their ability to resist methicillin. The process of methicillin resistance is encoded by the presence of chromosomal mecA gene. The genetic information of MRSA gives it the ability to resist all penicillins, and cephalosporins (Walther et al. ,2006).

Ingestion of contaminated food with MRSA strains may increase the risk of becoming carriers or infected by this m.o., So it is necessary to take the suitable measures to control or even prevent food contamination by this mo. (EFSA, 2010).

So, this work was planned to study the prevalence of S.aureus in fish products as well as molecular typing of MRSA strains isolated from processed fish products.

\section{Materials and Methods Samples}

A total number of 200 samples (100 fish burger samples and 100 fish fillet samples) (25g from each sample) were collected aseptically in stomacher bags from different stores in Port-Said Governorate; Samples were clearly marked and submitted to the lab. in sterile containers for bacteriological examination.

Isolation and identification of S.aureus

Preparation of samples:
Two hundred and twenty five $225 \mathrm{ml}$ peptone water $(1 \%)$ was added to the stomacher bags containing 25 grams of each sample and mixed in the stomacher, centrifugated at $300 \mathrm{rpm}$ for 2 minute (ICMSF, 1978).

\section{Isolation of S.aureus:}

According to Quinn et al. (2002); processed samples were inoculated in peptone water for $24 \mathrm{~h}$ at $37^{\circ} \mathrm{C}$ and then a loopful was taken and inoculated on nutrient agar, 5\% sheep Blood agar, Mannitol salt agar and Baird parker agar media. All inoculated plates were incubated at $37^{\circ} \mathrm{C}$ for $24-48 \mathrm{hrs}$ and examined daily for bacterial growth.

\section{Identification of S.aureus:}

The suspected colonies were examined for their morphological characters, hemolytic activity on 5 $\%$ Sheep blood agar, microscopical examination and biochemical characters according to (Quinn et al., 2002).

\section{Antimicrobial susceptibility}

Testing by disc for detection of (MRSA) strains

The susceptibility to Methicillin antibiotic was tested according to the procedures of (NCCLS, 2007) using disc diffusion technique. The susceptibility of the strains was determined according to the diameter of inhibition zone.

Molecular typing of MRSA strains:

1- DNA extraction from MRSA strains according to (Van eys et al., 1989).

2- Estimation of purity and 
concentration of DNA according

to Sambrook and Russel, (2001)

- Spectrophotometer was used to determine the concentration and purity of the extracted DNA by estimating the optical density at wave lengths of 260 and $280 \mathrm{~nm}$. -The concentration was calculated as follows: one OD at $260 \mathrm{~nm}=50$ ug $/ \mathrm{ml}$.

3-polymerase chain reaction (PCR):

Samples of DNA were tested [in 50 $\mu \mathrm{l}$. Reaction volume in a $0.2 \mathrm{ml}$ PCR tube, containing PCR buffer] (50 $\mathrm{mMKCl}, 10 \mathrm{mMtris}-\mathrm{HCl}$, $1 \mathrm{mM} \mathrm{Mgcl}_{2}$ ) each dNTPS $200 \mathrm{uM}$ each ( dATP , dGTP , dCTP and dTTP ), [ Two pairs of primers each at 50 picomol / reaction ] and 0.5 of taq DNA polymerase . After layering 40ul of mineral oil, thermal cycling was done in a programmed heating block (Coy vorporation, Grasslake, Michan, USA). A control negative PCR reaction was included with no template in this assay.

- PCR Protocol of mec gene according to (McClure et al., 2006)

Step 1: Initial Denaturation at 94 ${ }^{\circ} \mathrm{C}$ for $5 \mathrm{~min}$.

Step 2: Denaturation at $94{ }^{\circ} \mathrm{C}$ for 45 sec.

Step 3: Annealing at $50{ }^{\circ} \mathrm{C} 45 \mathrm{sec}$.

Step 4: Extension at $72{ }^{\circ} \mathrm{C}$ for 45 sec.

- Cycles repeated for 35 times and proceeded by initial denaturation at $95{ }^{\circ} \mathrm{C}$ for $5 \mathrm{~min}$. and followed by final extension at 72 for $10 \mathrm{~min}$.

\section{4- Agarose gel electrophoresis:}

Ten $\mu \mathrm{l}$ of amplified PCR products were analyzed by electrophoresis on $2 \%$ agarose gel stained with $0.5 \mu \mathrm{g}$ of ethedium bromide / $\mathrm{ml}$. Electrophoresis was made in $1 \mathrm{X}$ TAE buffer at 80 volt for 1 hour. Gels were visualized under UV transilluminator (UVP, UK) then photographed.

Table (1): list of primers used for PCR assay

\begin{tabular}{|c|c|c|}
\hline Primer & Primer sequence (5'-3') & $\begin{array}{c}\text { Size of amplified } \\
\text { product (bp) }\end{array}$ \\
\hline mecA-F. & GTA GAA ATG ACT GAA CGT CCG ATA A & \multirow{2}{*}{$310 \mathrm{bp}$} \\
\hline mecA-R. & CCA ATT CCA CAT TGT TTC GGT CTA A & \\
\hline
\end{tabular}

\section{Results}

Table (2): Number and percentage of S. aureus strains isolated from fish products:

\begin{tabular}{|c|c|c|c|c|c|c|c|}
\hline \multirow[b]{2}{*}{$\begin{array}{l}\text { Type of } \\
\text { samples }\end{array}$} & \multirow[b]{2}{*}{$\begin{array}{c}\text { No of } \\
\text { examined } \\
\text { samples }\end{array}$} & \multicolumn{6}{|c|}{ No. \& percentage of $S$. aureus } \\
\hline & & $\begin{array}{c}\text { No of } \\
\text { Coagulase } \\
\text { +ve } S . \\
\text { aureus }\end{array}$ & $\%$ & $\begin{array}{c}\text { No of } \\
\text { Coagulase } \\
\text {-ve } S . \\
\text { aureus }\end{array}$ & $\%$ & $\begin{array}{l}\text { Total No } \\
\text { of } \\
\text { S.aureus } \\
\text { strains }\end{array}$ & $\%$ \\
\hline $\begin{array}{c}\text { Fish } \\
\text { burger }\end{array}$ & 100 & 14 & 14 & 4 & 4 & 18 & 18 \\
\hline Fish fillet & 100 & 4 & 4 & 1 & 1 & 5 & 5 \\
\hline
\end{tabular}


Table (3): Number and percentage of MRSA strains isolated from fish products (based on antibiotic sensitivity):

\begin{tabular}{|c|c|c|c|c|c|c|}
\hline \multirow{2}{*}{$\begin{array}{l}\text { Types of } \\
\text { samples }\end{array}$} & \multirow{2}{*}{$\begin{array}{l}\text { Number of } \\
\text { Coagulase +ve } \\
\text { S. aureus }\end{array}$} & \multicolumn{2}{|c|}{$\begin{array}{l}\text { MRSA } \\
\text { strains }\end{array}$} & \multirow{2}{*}{$\begin{array}{c}\text { Number of } \\
\text { Coagulase } \\
\text {-ve } S . \\
\text { aureus }\end{array}$} & \multicolumn{2}{|c|}{$\begin{array}{l}\text { MRSA } \\
\text { strains }\end{array}$} \\
\hline & & No. & $\%$ & & No. & $\%$ \\
\hline Fish burger & 14 & 3 & $21 \%$ & 4 & 0 & 0 \\
\hline Fish fillet & 4 & 0 & $0 \%$ & 1 & 0 & 0 \\
\hline Total & 18 & 3 & $17 \%$ & 5 & $\mathbf{0}$ & $\mathbf{0}$ \\
\hline
\end{tabular}

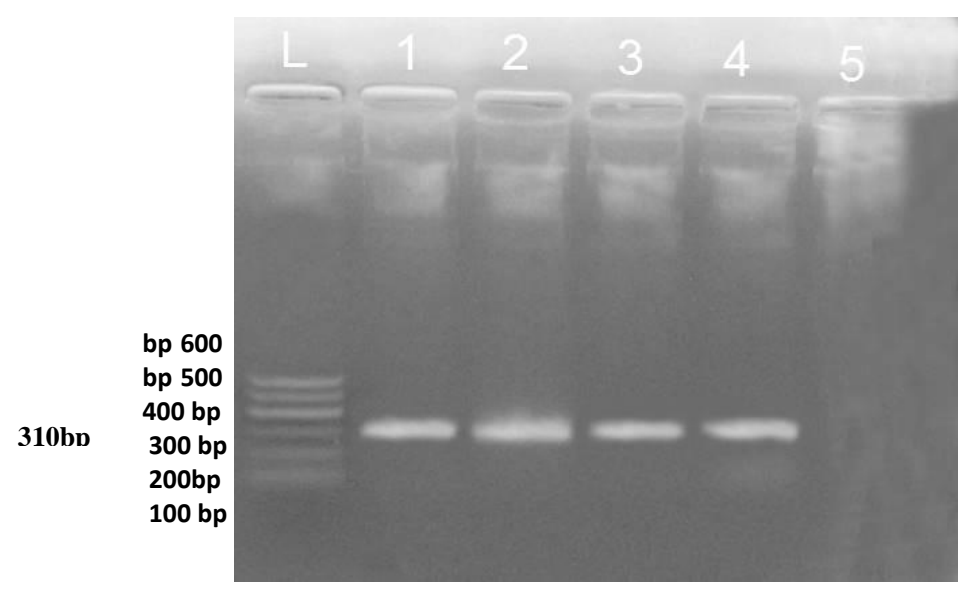

ing PCR assay

\section{L: (100 bp DNA ladder)}

Lane 1: Control positive S.aureus for mecA gene

Lanes 2, 3, 4: showed positive S.aureus strains for mecA gene (310 bp)

Lane 5: control negative ( E. coli)

\section{Discussion}

$S$. aureus is believed to be the third main causative pathogen of foodborne diseases transmitted by fish and fish products in the European Union (EFSA, 2009).

In the present study, the prevalence of coagulase +ve $S$. aureus was $(14 \%)$ in fish burger samples and $(4 \%)$ in fish fillet samples. On the other hand, the prevalence of Coagulase -ve $S$. aureus was (4\%) in fish burger samples and (1\%) in fish fillet samples as shown in Table (2) .These results agreed with that obtained by Daniel et al., (2012) and Sergelidis et al. , (2014). The higher prevalence of $S$. aureus in fish burger was due to the human handling during processing 
of fish products. Contamination may occur due to poor sanitary conditions, or bad storage conditions (Normanno et al., 2007). As regards to the results of antibiotic susceptibility testing as shown in Tables (3), the prevalence of MRSA strains was $17 \%$ from the total isolated coagulase positive $S$. aureus strains, while none of the coagulase negative $S$. aureus strains proved to be MRSA. Resistance to methicillin occurred mostly due to the presence of mecA gene on $S$. aureus chromosome which is responsible for the production of Penicillin binding protein $\mathrm{PBP}_{2 \mathrm{a}}$. (Ito et al., 2003).

In this work, PCR protocol was used for amplification of $310 \mathrm{bp}$ fragment of mecA gene in the isolated MRSA strains, as shown in Fig.(1), all the tested MRSA strains were positive for mecA gene. These results agreed with those obtained by John (2003; Sajith et al. (2012); Rania et al. (2013).

In conclusion, $S$. aureus is a very important bacterial agents causing food-borne illness in human due to contamination of fish products. The combination of phenotypic and genotypic characterization of $S$. aureus is an effective epidemiological tool for identification of the isolates. PCR is a fast and accurate technique can be used for the detection of MRSA strains as compared with traditional methods.

\section{References}

Daniel, V.S.; Marta, L.C.; Paula, S. and Juan, J. R. (2012): Incidence and characterization of Staphylococcus aureus in fishery products marketed in Galicia (Northwest Spain). International Journal of Food Microbiology. 157 (2): 286-296.

EFSA, European Centre for Disease Prevention and Control (2009): European Centre for Disease Prevention and Control. The Community Summary Report on Food-borne Outbreaks in the European Union in 2007. EFSA Journal, 271.

EFSA, European Centre for Disease Prevention and Control (2010): The Community Summary Report on Trends and Sources of Zoonoses, Zoonotic Agents and Food-borne Outbreaks in the European Union in 2008. EFSA Journal 8 (1), 1496.

International Commission on the Microbiological Specification for food. "ICMSF" (1978): Microorganism in Foods, Their Significance and Method of Enumeration .2nd Ed Univ. of Toronto Press. Toronto Canada.

ItO, M.; Itou, T. and Shoji, Y. (2003): Discrimination between dog-related and vampire bat-related rabies viruses in Brazil by strainspecific reverse transcriptase polymerase chain reaction and restriction fragment length polymorphism analysis. J. Clin. Virol, 26 : 317-330. 
John, H. L. (2003): Methicillin (Oxacillin)-Resistant

Staphylococcus aureus Strains Isolated from Major Food Animals and Their Potential Transmission to Humans. Appl Environ Microbiol. 69 (11): 6489-6494.

Llewelyn, M. and Cohen, J. (2002): Superantigens: microbial agents that corrupt

immunity. Lancet Infect. Dis. 2, 156-162.

McClure, J. A.; Conly, J.M.; Lau, V.; Elsayed, S.; Louie, T.; Hutchins, W. and Zhang, $K$. (2006): Novel multiplex PCR assay for detection of the staphylococcal virulence marker Panton-Valentine leukocidin genes and simultaneous discrimination of methicillin susceptible from-resistant Staphylococci. J. Clin. Microbiol. 44: 1141-1145.

NCCLS (National Committee for Clinical Standards) (2007): Performance Standards for Antimicrobial Susceptibility Testing; FifteenthInformational Supplement According to CLSI. CLSI document M100 -S15. Clinical and Laboratory Standards Institute, Wayne, PA.

Normanno, G.; La Salandra, G.; Dambrosio, A.; Quaglia, N.C. ; Corrente , M. Parisi, A.; Santagada, G.; Firinu, A.; Crisetti, E. and Celano, G.V.(2007):Occurrence, characterization and antimicrobial resistance of enterotoxigenic Staphylococcus aureus isolated from meat and dairy products.
International Journal of Food Microbiology. 115 :290-296.

Quinn, P.J.; Markey, B.K.; Carter, M.E. and Donnelly, W.J.C.; Leonard, F.C. and Maguire, D. (2002): Veterinary Microbiology and Microbial diseses.1 published Blackwell science $1^{\text {st }}$ d.

Rania,M.K.;Mohamed,A.B. and Salah,F.A.(2013):MRSA detection in raw milk,some dairy products and hands of dairy workers in Egypt, amini-survey.Food Control. 33: (1): 49-53.

Sambrook, J.and Russell, D.W. (2001): Molecular Cloning: A Laboratory Manual. 3rd edition.Cold Spring Harbor Laboratory Press, Cold Spring Harbor.

Sajith, K. A.K.; Preetha, J. S.; Lakshi, S. Y.; Anandi, C. and Ramesh, R. (2012): Detection of $m e c A$ genes of Methicillin-Resistant Staphylococcus aureus by Polymerase Chain Reaction. International Journal of Health and Rehabilitation Sciences . 1 (2):6468.

Sergelidis, D. ; Abrahim, A.; Papadopoulos, T.; Soultos, N.; Martziou, E.; Koulourida, V.; Govaris, A.; Pexara, A.; Zdragas, A. and Papa, A. (2014): Isolation of methicillin-resistant Staphylococcus spp. from ready-to-eat fish products.LettApplMicrobiol. 59(5):500-506.

Shena, S.S. and Sanjeev, S. (2007): Prevalence of enterotoxigenic Staphylococcus 
aureus in fishery products and fish processing factory workers, Food Control, 18:1565-1568.

Sichewo, P.R.; Gono, R.K.; Muzvondiwa, J.V.; and Sizanobuhle, N. (2013): Isolation and Identification of Pathogenic Bacteria in Edible Fish: A Case Study of Fletcher Dam in Gweru, Zimbabwe. International Journal of Science and Research (IJSR). 2:269-273.

Van Eys, G.M.; Gravekamp, C.; Gerritsen, M.; Quint, W.; 232. 2262.
Cornlissen, S.J. and Terpstra, W. (1989): Detection of leptospira in urine

PCR.j.clinc.microbiol.27:2258-

Walther, B.; Friedrich, A. W.; Brunnberg, L.; Wieler, L. H. and Lubke-Becker, A. (2006): Methicillin-resistant

Staphylococcus aureus (MRSA) in veterinary medicine: a "new emerging pathogen"?.Berl. Munch TierarztlWochenschr. 119(5-6):222-

\section{التصنيف الجزيئي لعترات المكور العنقودى الأهبى مارسا المعزولة من المنتجات

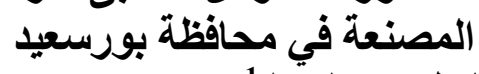

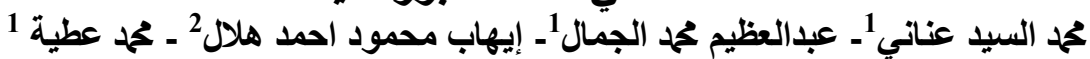

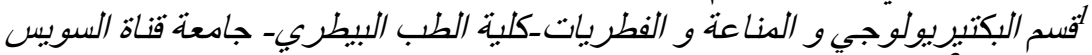

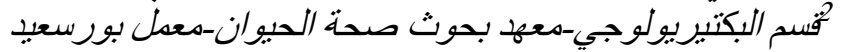

في هذه الدراسة تم إلقاء الضوء على تو اجد المكور العنقودى الذهبى في عدد 200عينة عشو ائية من

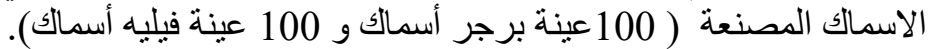

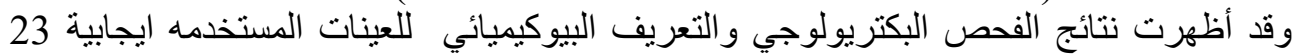

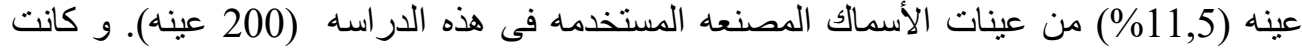

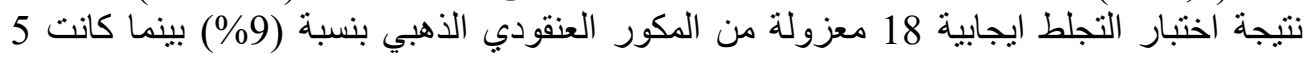
معزو لات سالبة لاختبار التجلط. وقد وجد ان العينات المعزوله الموجبه لاختبار التجلط من برجر الأسماك 14 معزولة بنسبة (14\%)

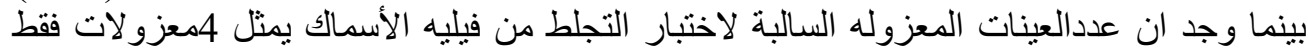

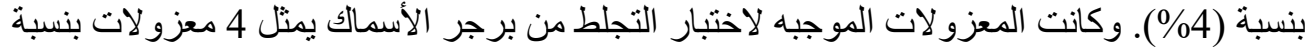

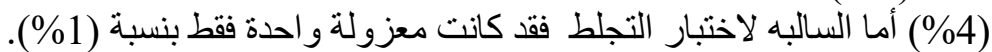

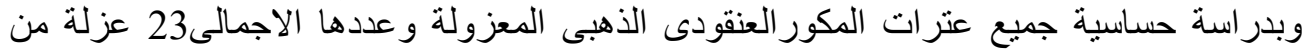

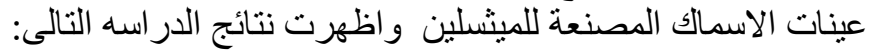

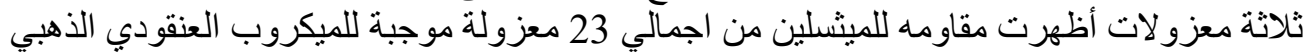

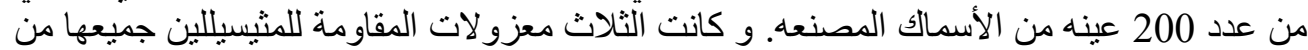

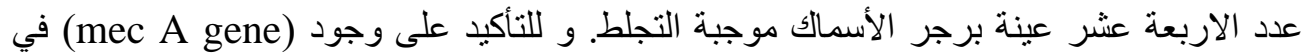

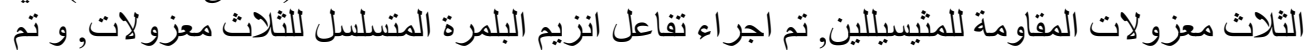
اثبات تو اجد (mec A gene) بهر. 